\title{
Landscape, Race, and Power on the Indo-Afghan Frontier, c.1840-c.1880
}

\author{
Jagjeet Lally \\ University College London
}

\begin{abstract}
Landscape defined a problematic of colonial rule on the nineteenth-century IndoAfghan frontier, connected, as it was, to contemporary ideas about difference novelly articulated in racial terms. This connection was the product of numerous developments, drawing on Enlightenment ideas about race and development and on historical analogy with the late eighteenth-century Scottish Highlands, as well as nineteenth-century ethnographic inquiry linking geographic isolation with racial preservation or descent. These 'noble savages' were also more likely to fall under the spell of charismatic Sufi leaders, spurring them to fierce resistance of political authority and acts of violence, and earning them a reputation for 'fanaticism'. Landscape also presented a problem for the expression of colonial power; for the ruggedness and remoteness of the frontier made the expatriate population vulnerable in an area where the colonial presence remained thin and where criminal prosecution could be easily evaded. The consequence was the Frontier Crimes Regulation, which devolved authority for the prosecution of crime and execution of justice to the heads of tribal societies according to local custom, and the Murderous Outrages Act, which empowered colonial officers to suspend due judicial process and order anachronistic and morally abhorrent forms of punishment. Just as ideas about race were ambivalent and contradictory, so, too, was colonial law.
\end{abstract}

Keywords: crime, ethnography, fanatic, murder, law, Pashtun

Words: 9490 
By looking to the frontier, a number of historians have lately sought to understand colonialism's ambivalences and contradictions, the chinks within colonial rule, and the spatial limits and variations of colonial power in South Asia and elsewhere. ${ }^{1}$ The Indo-Afghan frontier is a site that has been especially productive to these inquiries and is the focus of this article. ${ }^{2} \mathrm{~A}$ critically important strand of the growing body of research on the Indo-Afghan frontier and British colonial relations with Afghanistan has examined the ontology of colonial knowledge, focussing on the chronic misunderstandings of Afghans and Afghanistan by the British East India Company and Crown governments, their reproduction in the colonial archive and, thus, in colonial policy, as made so spectacularly evident in the disaster and carnage of the two British wars with Afghanistan (1839-42, 1878-80). ${ }^{3}$ Another has involved the examination of law and administration to show not only the difficulty facing the British in establishing a 'stable and secure' administration on the frontier, but the perception that violence was essential to this task, to the extent that it was instrumentalised in the very expressions of state power: law, criminal procedure and punishment, bureaucratic practice, and so forth. ${ }^{4}$ A number of other inquiries flow into these streams, whether on (the poverty of) colonial ethnography and its production of ideas of 'race' and 'tribe', or on tribal Islam and Muslim resistance to colonialism. ${ }^{5}$ Against this, others have tried to focus on indigenous actors and more pacific

\footnotetext{
${ }^{1}$ For an especially important collection of work that speaks to the themes of this essay: Sameetah Agha and Elizabeth Kolsky, eds., Fringes of Empire: People, Power and Places in Colonial India (New Delhi: Oxford University Press, 2009).

2 There is also a growing body of work on the northeastern frontier; for example: Gunner Cederlöf, Founding an Empire on India's North-Eastern Frontiers 1790-1840. Climate, Commerce, Polity (Delhi: Oxford University Press, 2014); Neeladri Bhattacharya and Joy L.K. Pachuau, eds., Landscape, Culture, and Belonging. Writing the History of Northeast India (Cambridge: Cambridge University Press, 2019).

${ }^{3}$ B. D. Hopkins, The Making of Modern Afghanistan (Basingstoke: Palgrave Macmillan, 2012); Martin J. Bayly, Taming the Imperial Imagination. Colonial Knowledge, International Relations, and the Anglo-Afghan Encounter, 1808-1878 (Cambridge: Cambridge University Press, 2016).

${ }^{4}$ Mark Condos, The Insecurity State. Punjab and the Making of Colonial power in British India (Cambridge: Cambridge University Press, 2017); Idem, "Fanaticism" and the Politics of Resistance along the North-West Frontier of British India', Comparative Studies in Society and History, vol. 58, no. 3 (2016), 717-45; Idem, 'Licence to Kill: The Murderous Outrages Act and the Rule of Law in Colonial India, 1867-1925' Modern Asian Studies, vol. 50, no. 2 (2016), 479-517; Elizabeth Kolsky, 'The Colonial Rule of Law and the Legal Regime of Exception: Frontier "Fanaticism" and State Violence in British India', American Historical Review, vol. 120, no. 4 (2015), 1218-46; Benjamin D. Hopkins, 'The Frontier Crimes Regulation and Frontier Governmentality' The Journal of Asian Studies, vol. 74, no. 2 (2015), 369-89; Robert Nichols, ed., The Frontier Crimes Regulation. A History in Documents (Karachi: Oxford University Press, 2013).

${ }^{5}$ On the former, for instance: Zak Leonard, 'Colonial Ethnography on India's North-West Frontier, 1850-1910' The Historical Journal, vol. 59, no. 1 (2016), 175-96. On the latter: Sana Haroon, Frontier of Faith; Magnus Marsden, Living Islam. Muslim Religious Experience in Pakistan's North-West Frontier (Cambridge: Cambridge University Press, 2005). See, also: Nile Green, ed., Afghanistan's Islam. From Conversion to the Taliban (Berkeley: University of California Press, 2016).
} 
topics, not least in discussions of Afghan history and literature as told through Afghan eyes or by the exertions of Afghan writers. ${ }^{6}$

This article makes two major interventions into this increasingly diverse yet disparate scholarship, through a combination of synthesis and examination of archival material from London and Lahore relating to the formative period roughly bookmarked by the two AngloAfghan wars of the nineteenth century. Always latent or implicit in much of the scholarship, the first half of this article argues for the central importance of landscape and ecology in scholarly analysis, for contemporaries understood the Afghan 'races' and their religion as entangled within the particularities of the ecology of their homeland. Pre-colonial characterisations of the Afghans distinguished them from the people of the sedentary zones within the heartlands of Indian polities, for many Afghans preferred to participate in mobile warrior bands and in semi-nomadic pastoral lifestyles. But British ideas concerning the character of the Afghans linked their distinctiveness to place, drawing on Enlightenment ideas about the influence of climate and topography upon human character (and, ultimately, 'race'), and on the immediate precedent of England's pacification of the Scottish Highlands and Ireland. Afghans were depicted as 'noble savages', this trope reinforced by the experience of fierce Afghan resistance to British rule, on the one hand, and the loyal service of Afghans in the British military, on the other. At the same time, European imperial regimes were by the nineteenth century facing their most vehement opposition from Islamic societies on the rugged forest or upland frontiers of their empires, their rulers thus drawing distinctions between the authentic Muslim uplander and the one relatively recently 'corrupted' by Sufism, the latter responsible for such 'fanatical' violence.

The second half of this article then turns to examine how these ideas about the Afghan character shaped colonial law on the frontier, focussing on the Frontier (Crimes) Regulation (FCR) and the Murderous Outrages Act (MOA). A spate of recent work on these statutes shows how spatialised were notions of sovereignty and the role or operation of the legal regime, proposing a rich range of concepts - including 'zones' of 'colonial exception' or of 'illegality' as well as 'frontier governmentality' - to illuminate the varied topography of empire(s). ${ }^{7}$ Nowhere have

\footnotetext{
${ }^{6}$ Green, Nile, and Nushin Arbabzadah, Afghanistan in Ink. Literature Between Diaspora and Nation (London: Hurst and Company, 2013).

${ }^{7}$ For a summary, see: Condos, 'Licence to Kill', 483; Hopkins, 'Frontier Crimes'. Aside from Condos' analysis, the MOA has also been studied by: Kolsky, 'Regime of Exception'. A collection of documents (with a brief introduction by their editor regarding the law and its legacy to present times) forms the only other serious study
} 
the FCR and MOA been examined together, a task which presents several surprising results. The first is that the law was 'raced' and thus, ultimately, 'spaced', for it was inflected with the patterns of thought about the Afghans and their homeland described in section I. The second is that both laws were a response to feelings of relative powerlessness. In the case of the MOA, which was instituted to deal with the assassination of frontier officers by Pashtuns, insecurity and powerlessness found expression through extreme violence, for the law permitted trial without record and retrograde forms of punishment (primarily, execution of a sort that had not only ceased in Britain, but also abrogated Pashtun custom and moral sensibility). In the case of the FCR, which was instituted to deal with crime (such as blood feud and murder) among subjects now under the 'civilising' hand of British rule, powerlessness resulted in the devolution of authority to groups of local elites - tribal elders selected and empowered by the colonial administration as its intermediaries - and the disappearance of a large portion of crime from the statistics. Overall, this article shows that the frontier was an imaginative space moulded by the colonial mind, and yet was afflicted by ambivalence.

The Pashtun constitute the dominant ethnic group of present-day Afghanistan and the Khyber Pakhtunkhwa, the latter corresponding to the Northwest Frontier Province (NWFP) carved out of the Peshawar district of the province of Punjab by the British in 1901 and forming what may also be described as the Indo-Afghan borderland. ${ }^{8}$ It would be remiss not to briefly touch upon how Pashtuns conceived of themselves and the space they inhabited, even though the

of the FCR at the time this article was written: Nichols, ed., Frontier Crimes Regulation. Saurabh Pant has recently examined the FCR as a case study in institutional path dependence: Saurabh Pant, 'The Frontier Crimes Regulation in Colonial India: Local Critiques and Persistent Effects' South Asia: Journal of South Asian Studies, vol. 41, no. 4 (2018), 789-905. He notes the ambivalence about instituting the law and about how effectively it functioned: op cit, 792-95. His work, however, begins its analysis with the 1887 revision rather than the original promulgation of the law. Its most innovative contribution is to examine the objections of 'local voices' to the revision and re-enactment of the law, but the evidence derives from the late 1910s onward, which is beyond the scope of the present study. Published after this article was accepted, Benjamin D. Hopkins, Ruling the Savage Periphery. Frontier Governance and the Making of the Modern State (Cambridge, Mass.: Harvard University Press, 2020), is a global history of the Indo-Afghan frontier, which Hopkins argues was a laboratory for the development of administrative practices (of physical and cultural enclosure and containment, rather than integration and assimilation) transported across the British imperial world where colonial administrators deemed the local population to be similarly 'savage' and 'uncivilised' as they deemed the Pashtuns. The FCR is the centrepiece of this analysis.

${ }^{8}$ The dangers of conflating the larger category 'Afghan' with the 'Pashtun' and also with 'Pathan' (a term with multiple meaning operative in north India) are well-known to specialists, save to say here that the processes that produced their conflation have been dated back to the early nineteenth century. See: Shah Mahmoud Hanifi, 'Quandaries of the Afghan Nation' in Under the Drones, ed. by Shahzad Bashir and Robert D. Crews (Cambridge, Mass.: Harvard University Press, 2012), especially 86, 89-93, 100. 
disentangling of ideas about landscape and race concocted within the colonial mind is the focus of this section. In fact, such context not only avoids the reification of state-centric imaginations of Pashtuns and the Indo-Afghan frontier, whether those of nineteenth-century colonial elites or their Mughal predecessors; it also helps spotlight what was distinctive about colonial knowledge formations and helps explain some of their consequences. ${ }^{9}$

By the nineteenth century, the British and their European nation-state counterparts thought of political sovereignty in the Westphalian sense: states possessed exclusive sovereignty over their territory, demarcated by borders. This provided an impetus to cartographic enterprises, which permitted European rulers to shade in red their lands on a map, and which rendered territory somewhat abstract. ${ }^{10}$ By contrast, Indian rulers thought to a greater extent about sovereignty as stacked or layered, with a great king above lesser kings, landlords, and the mass of society, while also thinking about the spread or reach of their authority in terms of political networks and allegiances; hence, for instance, marriage alliances between the Mughal imperial household and the important Rajput dynasties. ${ }^{11}$ The accumulation of power was also inseparable from the formation and mobilisation of less obviously or overtly political sorts of networks, such as ties with merchant families or religious lineages, as has been revealed by the study of Mughal princely households as they readied themselves to fight in wars of succession, for example. ${ }^{12}$

Pashtun elites, naturally, were also embedded within such networks. ${ }^{13}$ Particularly important were connections forged from the fifteenth century through marital alliance with Sufi blessed men and their families, for they belonged to lineages that criss-crossed and integrated central

\footnotetext{
${ }^{9} \mathrm{I}$ am indebted to one of the reviewers for a nudge in this direction and a number of useful suggestions, only some of which I have been able to pursue in order to offer the proceeding sketch.

${ }^{10}$ Ian J. Barrow, Making History, Drawing Territory: British Mapping in India, c. 1756-1905 (New Delhi: Oxford University Press, 2003).

11 Christopher Bayly and Susan Bayly, 'Eighteenth-Century State Forms and the Economy' in Arrested Development in India. The Historical Dimension, ed. by Clive Dewey (New Delhi: Manohar, 1988), especially 75-76 for discussion of the vertical and horizontal competition within the state system drawn from the work of Burton Stein and André Wink. The Rajput example is especially pertinent since, like the Pashtun, they, too, were long held as 'feudal' and 'tribal'. The history and purpose of marital alliances (within and beyond boundaries of identity such as lineage, caste, and religion) has lately been surveyed by: Sabita Singh, The Politics of Marriage in Medieval India: Gender and Alliance in Rajasthan (New Delhi: Oxford University Press), especially 49-84.

${ }^{12}$ Munis D. Faruqui, The Princes of the Mughal Empire, 1504-1719 (Cambridge: Cambridge University Press, 2012).

${ }^{13}$ For discussion of the importance of mercantile and other networks to Afghan state formation: Jagjeet Lally, 'Beyond "Tribal Breakout": Afghans in the History of Empire, c. 1747-1818' Journal of World History, vol. 29, no. 3 (2018), 369-97.
} 
Eurasia and the Indian subcontinent, which were also interleaved with intellectual, mercantile, and political networks, and through which arose opportunities for patronage and the accumulation of material or other resources. At the same time, saintly figures played an important role in resolving disputes between Pashtun tribes. ${ }^{14}$ Afghan patrons from the seventeenth century onward commissioned genealogies tracing (or creating?) these connections, such was their value and power. ${ }^{15}$ As for the mass of Afghan folk, many were settled agriculturalists, but a large proportion - perhaps larger than among other groups from other regions in south Asia - were semi-nomadic and thus mobile. ${ }^{16}$

Historically, many Pashtun moved between the Afghan highlands and the north Indian plain in search of fresh pasture for their flocks, thus combining pastoralism and seasonal migration, on the one hand, with trade in surpluses of livestock, animal products, fruits, and nuts, as well as the sale of their fighting power in the subcontinent's military labour markets, on the other. ${ }^{17}$ Indian rulers valued the controlled injection of men of arms into their forces during the winter campaign and conquest season, while the productions of the highlands complemented those of the lowland markets across north India (and perhaps as far east as Bengal and as far south as the Deccan) in which they found sale, bringing these two worlds into interdependence. ${ }^{18}$ In part, because this fighting power was better channelled into their own forces than those of their rivals, Afghan recruits filled the irregular armies of the Mughals and succeeding political authorities laying claim over the Indo-Afghan frontier and Punjab; namely, the Sikhs (from 1818) and British (from 1849). ${ }^{19}$

\footnotetext{
${ }^{14}$ Nile Green, 'Blessed Men and Tribal Politics: Notes on Political Culture in the Indo-Afghan World', Journal of the Economic and Social History of the Orient, vol. 49, no. 3 (2006), 344-60.

${ }^{15}$ Nile Green, 'Tribe, Diaspora, and Sainthood in Afghan History' The Journal of Asian Studies, vol. 67, no. 1 (2008), 171-211.

${ }^{16}$ Among other facts, some indication of the importance of sedentary agriculture is given by the extension of tiyul (prebendal rights, akin to the jagir) in the eighteenth century: Lally, 'Beyond "Tribal Breakout", 390.

${ }^{17}$ Dirk H. A. Kolff, Naukar, Rajput and Sepoy. The Ethnohistory of the Military Labour Market in Hindustan (Cambridge: Cambridge University Press, 1990), for a classic work that also addresses the changing role of ethnoracial identities within the military labour market, as pertinent to this section of the present analysis.

${ }^{18}$ Jagjeet Lally, India and the Silk Roads. The History of a Trading World, c. 1700-1918 (London: C. Hurst \& Co, 2020), especially chapters 1,3 , and 4.

${ }^{19}$ For some indication of the Afghan groups who offered their services as mercenaries and fighters in Punjab's military labour market, one only need leaf through the Punjab Characters Album, bought by the India Office in 1919 but painted by Indian artists (probably in Amritsar, the summer capital of the Sikh polity) in 1838-39 for a European patron: British Library, London, Add.Or.1347 to Add.Or.1396.

Of course, British forces absorbed Afghan fighting power long before the annexation of the Northwest Frontier because Afghan mercenaries travelled across north India at the start of the campaign season in search of the most lucrative opportunities. Mountstuart Elphinstone, whose account of his 1808 mission is discussed below, notes the use of Yusufzai tribesmen, for instance: An Account of the Kingdom of Caubul (London: J. Murray, 1815), 350 .
} 
From the Pashtun vantage point, in summation, the geography of these material-politicalreligious networks - and the very real or imagined situation of the Pashtuns within them amounted to something markedly different from nineteenth-century colonial ideas about the Pashtun and their relationship to territory. Only a very small number of East India Company officers had journeyed through Afghanistan to central Asia and Iran, but even this did not lead to the production of a coherent body of knowledge about Afghans or Afghanistan before c. $1800 .{ }^{20}$ It is perhaps because they had primarily came into contact with itinerant Afghan mercantile peoples and men of arms, or those of Afghan descent settled on the subcontinent, that the British came to imagine Afghans as the impoverished shepherds of the rugged uplands. Their first sustained contact with what is present-day Afghanistan came in consequence of the diplomatic mission made by the Scottish Enlightenment-Orientalist, Mountstuart Elphinstone, to the court of the Afghan kingdom in Peshawar in 1808. Elphinstone's account contained chronic misunderstandings of the Pashtun tribes and of Afghan social and political organisation but formed a new colonial 'episteme', the foundation for further inquiry. ${ }^{21}$ Especially important for the present analysis, Elphinstone imposed the Romantic model of the history of Scots clansmen - no doubt drawing on the outpouring of historical, pictorial, and literary works in the wake of the Jacobite Rebellion of 1745 and the associated pacification of the Celtic fringe and its 'noble savages' - onto his analysis of Pashtun 'Highlanders'. ${ }^{22}$

Elaborating such an understanding through similitude or analogy was fairly typical of Scottish Enlightenment ways of thinking about racial difference and civilisational progress, the results of which found most concrete expression in the form of the stadial theory of development. ${ }^{23}$ Pashtun tribesmen - like the Celts or Gaels of Britain and Ireland - were painted as rude and

\footnotetext{
${ }^{20}$ Lally, India and the Silk Roads, chapter 7 for a detailed analysis of colonial knowledge of the Indo-Afghan borderland and the larger world orbited by Afghans and other groups connected to caravan trade. See, also: Bayly, Taming the Imperial, 295-304, for a chronological list and details of European travellers to Afghanistan from 1793 to 1878.

${ }^{21}$ The ontology of colonial knowledge about Afghanistan and its inhabitants has lately been interrogated in depth by: Hopkins, Modern Afghanistan; Bayly, Taming the Imperial Imagination, especially 119-75.

${ }^{22}$ Elphinstone, Account, for instance 173, 408, and 514, for a comparison of clanship with tribal organisation, and the titles of laird and khan. See, also: Zak Leonards, "Muslim 'Fanaticism" as Ambiguous Trope: A Study in Polemical Mutation' in Mountstuart Elphinstone in South Asia. Pioneer of British Colonial Rule (London: Hurst Publishers, Oxford University Press, 2019), especially 97-99. For something of the market for pictures of Highland landscapes that had sprung up shortly after the Jacobite rebellion; see: Simon Schama, Landscape and Memory (London: Harper Collins, 1995), 466-71. For a sense of the boom in writing about the Highlands, see: Fredrik Albritton Jonsson, Enlightenment's Frontier. The Scottish Highlands and the Origins of Environmentalism (New Haven: Yale University Press, 2013), 50.

${ }^{23}$ Silvia Sebastiani, The Scottish Enlightenment. Race, Gender, and the Limits of Progress (New York: Palgrave Macmillan, 2013).
} 
untamed, barbarous and violent, but possessed the potential to be civilised if their energies were channelled appropriately. These ideas had acquired currency by the mid-century, receiving fresh impetus when Pashtun recruits supported British efforts to suppress the Indian Rebellion of 1857-58, fighting alongside Highland regiments. ${ }^{24}$ The reportage and subsequent commemoration of their efforts produced imagery that drew the empire's two sets of noble savages into direct connection, prompting the development of martial races ideology, a loose body of thought - rather than a formal theory per se - specifying the advantages of restricting recruitment into the armed forces to India's most martial and warlike groups, foremost among them the Pashtun, Punjabis, and Gurkhas. ${ }^{25}$

There were two other projects, both inconclusive, the effect of which was to nevertheless distinguish Afghans (often, more specifically, the Pashtun) as racially distinctive, if not 'pure'. In both, emphasis was placed on the Afghans' relative spatial isolation on the upland frontier of south Asia, for this had largely prevented the métissage of 'foreign' peoples with those on the subcontinent's lowlands and littoral that resulted in the former's racial 'degradation'. The first of these was the search for the 'lost tribes of Israel' in Afghanistan; a project over which doubt had already been cast by the mid-century following the disappointment of the Jewish Christian scholar-missionary, Reverend Dr Joseph Wolff (1795-1862), with the lack of correspondence between Pashtun and Jewish physiognomy, language, and traditions. ${ }^{26}$ The second, which gained far greater traction, was the theory of Aryan descent; a project whose origins owed a great deal to the work of Scottish Orientalists at home and in the service of the East India Company, and developed from the mid-century onward through rigorous 'anthropological' study of Afghan ethnogenesis, a subject that had hitherto been largely based

\footnotetext{
${ }^{24}$ Heather Streets, Martial Races. The Military, Race, and Masculinity in British Imperial Culture, 1857-1914 (Manchester: Manchester University Press, 2004), especially chapters 1-2. See, also: Edward M. Spiers, 'Highland Soldier: Imperial Impact and Image' Northern Scotland, vol. 1 (new series), no. 1 (2010), 76-87, here especially 80-81.

25 The only 'canonical text' outlining the advantages of such restrictive recruitment was written by Sir George MacMunn (1869-1952), who served for forty years in the imperial military services, much of this time in British India: The Martial Races of India (London: Sampson Low, Martson \& Co, 1933?). Martial races 'ideology' has been much interrogated for its (in)consistency and actual application (or not), see: Gavin Rand and Kim Wagner, 'Recruiting the 'Martial Races': Identities and Military Service in Colonial India' Patterns of Prejudice, vol. 46, nos. 3-4 (2012), 232-54.

${ }^{26}$ Joseph Wolff, Researches and Missionary Labours Among the Jews, Mohammedans, and Other Sects (London: n.p., 1835), 228-238, for a summary of his various inquiries, and 238, for a pronouncement of his doubts. More optimistic was the work of the British diplomat and politician, who never set foot in Afghanistan: George Henry Rose, The Afghans, the Ten Tribes, and the Kings of the East (London: Hatchards, 1852). The 'search' continued - or, rather, the trope retained sufficient currency that it resurfaced later in the century. See, not least, the work of the eminent scholar and explorer of Afghanistan: H.W. Bellew, The Races of Afghanistan (Calcutta: Thacker, Spink, and Co., 1880), 15.
} 
on anecdotal evidence. ${ }^{27}$ This project arguably solidified formerly fluid ideas of social identities and 'tribe', rendering tribal identities less fungible, as Benjamin Hopkins and Elizabeth Kolsky argue, although the textual 'codification' of supple forms of oral knowledge about Afghan genealogy was initiated by Afghan patrons themselves in the eighteenth century, if not earlier. ${ }^{28}$

To be clear, this was no stateless 'Zomia' into which people had fled to avoid the depredations and persecutions of sedentary states in the plains, such as fiscal extraction, forced labour, and military conscription. ${ }^{29}$ In the first place, some Pashtuns seasonally migrated to the plains, where they freely exchanged their goods and (military) services, as aforementioned. Yet, more importantly, this space was home to successive political authorities of a similar form to those the British encountered elsewhere on the Indian subcontinent. Babur's (1483-1530) kingdom in Kabul, after all, was the launchpad for his later march into Hindustan to defeat the last of the Delhi sultans and found the Mughal Empire in 1526, and Kabul remained an important Mughal subah (province). A little over two centuries later, in 1747, Ahmad Shah Durrani (r. 1747-72) united several scores of Pashtun tribes to establish a political capital in Kandahar, and from there expanded outward, laying (in)direct claim over Herat and Kashmir, Sindh and Punjab. Ahmad Shah is still celebrated in prose and verse as the father of modern Afghanistan, such outpourings beginning under his own patronage as he sought to establish a typically IndoPersianate cosmopolitan polity: he invited and commissioned the services of architects and litterateurs, Islamic jurists and philosophes to build the physical and institutional edifices of the Durrani polity. ${ }^{30}$ Indeed, far from being beyond the realm of civility, the 'burgeoning Afghan imperial capitals [Kabul, Peshawar]' of the mid-eighteenth century, Waleed Ziad has highlighted, 'attracted Sufis and ulama from Hindustan, eventually becoming fulcrums of reoriented intellectual-exchange circuits'. ${ }^{31}$ In earlier times, too, Afghan cultural production

\footnotetext{
${ }^{27}$ Ballantyne, Aryanism., especially 33-34, 48-54; Leonard, 'Frontier Ethnography'. Note, the Celt occupied an ambiguous place within the theory, and some writers were at pains to dissociate Scots from Celts and Gaels and their proximity to the Teuton instead: Francis Fowle, 'The Celtic Revival in Britain and Ireland: Reconstructing the Past c. AD 1600-1920' in Celts. Art and Identity, ed. by Julia Farley and Fraser Hunter (London: British Museum Press, 2015), 254-55.

${ }^{28}$ Hopkins, 'Frontier Crimes', 373; Kolsky, 'Regime of Exception', 1227-28. For the prior origins of this project, see, below: n. 22.

${ }^{29}$ For a now classic exposition of this thesis: James C. Scott, The Art of Not Being Governed: An Anarchist History of Upland Southeast Asia (New Haven: Yale University Press, 2009).

${ }^{30}$ Lally, "Beyond "Tribal Breakout"', 384-85 for a summary of recent scholarship on these endeavours, and passim, for a history of the Durrani state.

${ }^{31}$ Waleed Ziad, 'Transporting Knowledge in the Durrani Empire. Two Manuals of Naqshbandi-Mujaddidi Sufi Practice' in Afghanistan's Islam. From Conversion to the Taliban, ed. by Nile Green (Oakland: University of California Press, 2017), p. 105.
} 
and patronage could rival that of the Mughal state. Khushhal Khan Khatak (1613-89), for instance, was chief of the Khatak tribe as well as a poet and prose author in Pashto of great renown, his prose subjects ranging from falconry to medicine and the proper art of government.

He was born into a family incorporated into the Mughal state through imperial service, but fell foul of the Mughal emperor in the 1660s, openly criticising Aurangzeb (r. 1658-1707) in his Dastar Nama (1666), a sort of mirrors-for-princes in Pashto modelled on contemporary texts in circulation in the Mughal and wider Indo-Persianate worlds. ${ }^{32}$ Such hostility between the local and imperial levels of authority were not confined to this area, being part and parcel of Mughal politics, and Khushhal Khan was even pardoned and brought back into the fold for a while. Yet, by the time of the deepening involvement of the Company with Afghanistan from the 1820 s to the 1840 s, this space had been cast as difficult to govern and designated as 'Yaghistan' or land of the yaghis - a term, Sana Haroon notes, meaning anything from 'oily or slippery to uncontrollable or unmanageable' - which had entered colonial lexicon by the midcentury. ${ }^{33}$ Part of an explanation can be teased out by returning to Khushhal Khan Khattak's times. As chief of the Khattak tribe, his role as an imperial serviceman - taken in return for sanctioning of his watan jagir (hereditary rights to his ancestral land) - involved the collection of taxes and tolls and the maintenance of the free movement of traffic. ${ }^{34}$ In this, he and his forebears came into conflict with neighbouring tribes, not least the Yusufzai, who had settled in the area around the Khyber Pass and the Peshawar valley by the early Mughal era, and thus straddled the commercially and geostrategically important highway from central Asia through Kabul to north India. ${ }^{35}$

The response of some Afghan tribes to the intrusion of larger political authorities - in the form of taxation of their slender surpluses, most especially - had been armed resistance and rebellion, predatory activity and brigandage. This served as a symbolic assault on the power of the state and, in some cases, came in consequence of actual hardship. In other cases, however, raiding in pursuit of liquid wealth and military resources (including livestock) was a form of

\footnotetext{
${ }^{32}$ Mikhail Pelevin, 'Khwushhāl Khān Khat'ak' in Encyclopaedia of Islam, Three, ed. by Kate Fleet, Gudrun Krämer, Denis Matringe, John Nawas, and Everett Rowson (Leiden: Brill, 2019) (accessed online: 2 July 2020): http://dx.doi.org.libproxy.ucl.ac.uk/10.1163/1573-3912_ei3 COM 35573

${ }^{33}$ Haroon, Frontier of Faith, 30-31. It has been argued that the term had currency among indigenous powerholders before it entered colonial lexicon: B. D. Hopkins, 'Jihad on the Frontier: A History of Religious Revolt on the North-West Frontier, 1800-1947’ History Compass, vol. 7, no. 6 (2009), 1459-69, here 1461.

${ }^{34}$ Pelevin, 'Khwushhāl Khān Khat’ak'.

${ }^{35}$ Nichols, Settling the Frontier, 1-15.
} 
primitive accumulation. It permitted the build-up of the tribesmen's military strength to better attract the patronage of those warlords and courtly centres requiring the service of men of arms in the campaign season, the number of whom had proliferated on the Indian subcontinent by the eighteenth century, and among whom was Ahmad Shah himself. ${ }^{36}$ The Pashtun homeland was thus cast - if not as one of disorder - then certainly outside order or else denigrated by the Mughals, since some tribal leaders preferred to remain outside the world of Mughal (and postMughal) courtly civility, and as some Pashtun tribes generally remained outside the forms of political economy and the revenue-bureaucratic apparatus of the Mughal state. ${ }^{37}$ Ideas about Pashtun 'difference' in the early modern Indo-Islamicate world were not articulated in what could be called 'racial' language, drawing instead, for instance, on Khaldunian notions about the interdependence of the world of the steppe to that of the sown, of the ghazi (raider-warrior) and the mirza (prince). ${ }^{38}$

Generally too diffuse and too divided to pose a more serious challenge to central authority beyond routine raiding and banditry, the Yusufzais were episodically stirred by charismatic leaders whose spiritual lineage transcended tribe or clan identity. ${ }^{39}$ Under their spell, the scale of tribal resistance shifted from isolated attacks on the state and its representatives to a larger assault or rebellion. Bayazid Ansari (b. 1525), the founder of the heterodox Roshaniyya Sufi order, is notable as such a leader in the pre-colonial period. ${ }^{40}$ But it was another leader, alienated by the effects of the Company's expansion from the eighteenth century, who set in train a movement that coloured British understandings of the Indo-Afghan frontier. Born in 1786, Sayyid Ahmad and the followers of his Sufi-inspired revivalist movement migrated from Company territory in Bengal and Bihar to Peshawar on the Indo-Afghan frontier around 1824, the latter an area only recently wrested from the Durrani Afghan polity by the Sikhs. ${ }^{41}$ There, his spiritual authority and sphere of influence loosely overlapped with that of the Akhund of Swat, Abdul Ghaffur (1794-1877), a powerful Yusufzai mullah. Sayyid Ahmad was able,

\footnotetext{
${ }^{36}$ Lally, 'Beyond "Tribal Breakout", 375-84.

${ }^{37}$ Such was their denigration, that Afghans from the Mughal-era onwards attempted to 'retrieve' if not construct Afghan origins and history as honourable through the patronage of literary production: Green, 'Tribe, Diaspora, and Sainthood', here 183-86.

${ }^{38}$ For a neo-Ibn Khaldunian formulation of the rise and fall of empires: Jos J.L. Gommans, The Indian Frontier. Horse and Warband in the Making of Empires (Delhi: Manohar, 2018), 51-77. For a juxtaposition of the ghazi and mirza ideals: Idem, Mughal Warfare: Frontiers and the High Roads of Empire 1500-1700 (London: Routledge, 2002), especially 39-40.

${ }^{39}$ Green, 'Blessed Men'.

${ }^{40}$ Nichols, Settling the Frontier, 10-12.

${ }^{41}$ Seema Alavi, "Fugitive Mullahs and Outlawed Fanatics": Indian Muslims in Nineteenth Century Trans-Asiatic Imperial Rivalries', Modern Asian Studies, vol. 45, no. 6 (2011), 1337-82, here 1340.
} 
nevertheless, to make common cause with Yusufzai tribesmen, who continued to obstruct Sikh political authority by blockading, raiding, kidnapping, and pillaging goods brought by caravan from the plains. When, in 1831, Sayyid Ahmed died in a skirmish as part of the larger jihad, his followers proclaimed him a shahid (martyr), and retreated into the mountains. There, in a village called Sitana on the Indus River in the Buner country, they established what the British official sources describe as a 'colony'. Through connections to supporters - mostly peasants from Bengal and Bihar - the colonists and their Pashtun allies were able to collect subscriptions and amass recruits to contest Sikh rule. ${ }^{42}$

The language of jihad or spiritual uprising came to British attention through dialogue with autochthonous participants - Afghan, Pashtun, Punjabi, Sikh - as early as the 1820s, well before Company men moved more deeply into this space, before the first British campaign in Afghanistan and the two wars with the Sikhs (1845-46, 1848-49). ${ }^{43}$ The conclusion of the latter made the Peshawar valley part of Company territory and made the British targets of the colonists' jihads and the tribal raids. ${ }^{44}$ Sayyid Ahmad was connected to the princely rulers of south India, where Afghans had long-since settled, brought along by networks of trade and mercenary service, as Chandra Mallampalli's fascinating and meticulous recent study has brought to light,. ${ }^{45}$ From around the time of the first British war with Afghanistan, when British paranoia of foreign threats to her Indian Empire started to simmer, suspicions arose of the colony as the epicentre of a much larger Wahhabi conspiracy, therefore. ${ }^{46}$ Fearful that Sayyid Ahmad (or his successor) and their royal patrons might effect the end of British paramountcy on the subcontinent, the Company state on the frontier began to closely monitor the Sitana colonists.

\footnotetext{
${ }^{42}$ The most fulsome nineteenth-century histories of Sayyid Ahmad and the Sitana colony are: Adye, Sitana, especially 16-18; Gazetteer of the Peshawar District: 1883-4 (Calcutta: Calcutta Central Press Company, 1884), 174-78. Marsden and Hopkins' Fragments gazes upon the Sitana colony to examine frontier revolt. Op. cit., 8687, for the factors making for Sayyid Ahmad's traction with the Pashtun tribesmen despite not being Pashtun himself.

${ }^{43}$ For a recent, rich investigation of the various mobilisations and meanings of jihad: Tariq Rahman, Interpretations of Jihad in South Asia. An Intellectual History (Boston: De Gruyter, 2018).

${ }^{44}$ Nichols, Settling the Frontier, 91-92.

${ }^{45}$ Chandra Mallampalli, A Muslim Conspiracy in British India? Politics and Paranoia in the Early NineteenthCentury Deccan (Cambridge: Cambridge University Press, 2017).

${ }^{46}$ See, for the fear of Muslims - presumed to be Wahhabis - from Patna and Kanpur travelling to join and enlarge the colony at Sitana: Punjab Archives and Library, Lahore, Political Department Proceedings (henceforth: PALP), 24.2.1855, Nos. 38-40; PAL-P, 24.3.1855, No. 74; PAL-P, 16.6.1855, No. 24.
} 
From the 1840 s, they were commonly called the 'Hindustani fanatics' in light of their origins in north India (rather than the borderlands per se) and the original meaning of fanatic (as reflecting religious excess). There were a range of alternate terms - conveying different attitudes or points of emphasis with respect to their activities and the potential threat they posed - which officials continued to use into the twentieth century: "from simple "enthusiasts" to militant "crescentaders" to "mujahidin" [the term used by the colonists themselves] and even "talibs". ${ }^{47}$ More generally, 'ghazi' (raider-warrior) and 'ghazism' were also employed, not only because they were terms used by indigenous agents themselves, but also because the connection to holy war referenced the Crusades and the contest between Christianity and Islam that had so defined European understandings of the latter (and had been invoked during the Mutiny-Rebellion of 1857). ${ }^{48}$ The colonial administration became aware of the colonists' machinations against the newly-extended Company state in 1852, the initial burst of alarm dismissed and dispelled by Governor-General Dalhousie, with the state prosecuting and repatriating some of the colonists with a certain degree of leniency. ${ }^{49}$

Zak Leonards' excellent analysis demonstrates that fanaticism was both 'over-determined and under-defined', evolving 'into a floating signifier, a malleable construct that could service divergent polemical agendas. ${ }^{50}$ In large part, this was because the ethnographic work of Elphinstone, Henry Walter Bellew, and Septimus Smet Thorburn was inconsistent, let alone standing alongside other voices - those of administrators of diverse rank, expertise, and background, as well as indigenous actors - to form anything like a coherent and stable body of colonial knowledge, which it did not. ${ }^{51}$ Within colonial discourse, the term 'fanatic' did not necessarily decrease in usage after the 1840 s or 1850 s, but its charge shifted, gaining decisively more negative connotations by the 1860s and 1870s. In part, this was due to the violent agrarian revolt of the 'Moplahs' - the Mappila, the Muslim community of what is today Kerala - who were described as 'fanatics' and their protest as 'outrages' ${ }^{52}$ Two other factors helped inflect the shift in the meaning of 'fanatic'. The first was the Indian Rebellion of 1857, and the subsequent paranoia and fear of Muslims that was capable of crippling expatriate society or

\footnotetext{
${ }^{47}$ Marsden and Hopkins, Fragments, 80.

${ }^{48}$ Kolsky, 'Regime of Exception', 1232.

${ }^{49}$ Marsden and Hopkins, Fragments, 83.

${ }^{50}$ Leonards, 'Muslim 'Fanaticism', citations respectively 95 and 93.

${ }^{51}$ Ibid, 105.

52 K.N. Panikkar, Against Lord and State. Religion and Peasant Uprisings in Malabar, 1836-1921 (Oxford: Oxford University Press, 1989) especially 49-102 for details and causes of the various economic and social tensions - which were not limited to religious difference, despite the language of colonial officialdom and later analysis - that erupted as the mid-nineteenth century waves of revolt as well as the response from the state.
} 
else left its mark in newfound apprehension about the governance of Indian subjects. ${ }^{53}$ The second was born of nineteenth-century globalisation. The freer movement of people and ideas gave rise to anxiety of Wahhabism spreading from Arabia to other locales, animating a spectre - the 'phantom Wahhabi', a fundamentalist fixed on inciting Muslims to rise up against colonial authority. ${ }^{54}$ The same motilities also made possible the imagination of some panIslamic uprising in opposition to European power in one or several colonies, with the Ottoman Empire - as the last Muslim imperial power - its most likely coordinating centre. ${ }^{55}$

'Muslims', Mark Condos observes, 'were widely considered by Europe's imperial powers to be uniquely sensitive subjects who were difficult to govern and prone to violence and rebellion due to their inherently "fanatical" tendencies. ${ }^{56}$ By the close of the nineteenth century, campaigns of conquest and pacification fought by European regimes across Afro-Eurasia had produced a rhetoric with a repetitive vocabulary bent on demonising Muslims. But those 'gullible' mountaineers of the rugged or remote borderlands who had fallen under the influence of Sufism were seen as particularly restive and recalcitrant, earning them a reputation rewarded with a special lexicon - as 'fanatical', 'irrational', 'primitive', 'savage'. ${ }^{57}$ The colonial response to the resistance of such peoples often took the form of brutal pacification, ruthless punitive action, and savage warfare. ${ }^{58}$ Indeed, on the Indo-Afghan frontier, the Company followed its predecessors by attempting to channel the fighting power of Yusufzai and other tribesmen into its irregular armies, but ultimately struggled to actually subdue the Pashtun and thereby incorporate the Pashtun homeland. ${ }^{59}$ The early years of Company administration on the frontier saw hostility from the 'border tribes' and, in response, counteroperations of various sorts by the colonial forces (whether the institution of 'blockades', or

\footnotetext{
${ }^{53}$ Broadly, on this vast topic: Alex Padamsee, Representations of Indian Muslims in British Colonial Discourse (Basingstoke: MacMillan, 2005).

${ }^{54}$ Julia Stephens, 'The Phantom Wahhabi: Liberalism and the Muslim Fanatic in Mid-Victorian India' Modern Asian Studies, vol. 47, no. 1 (2013), 22-52, here especially 24.

${ }^{55}$ Umar Ryad, 'Anti-Imperialism and the Pan-Islamic Movement' in Islam and the European Empires, ed. by David Motadel (Oxford: Oxford University Press, 2014).

${ }^{56}$ Condos, 'Fanaticism', 721. See, also: Rebekka Habermas, 'Debates on Islam in Imperial Germany' in Islam and the European Empires, ed. by David Motadel (Oxford: Oxford University Press, 2014), 237.

57 Alexander Knysh, 'Sufism as an Explanatory Paradigm: The Issue of the Motivations of Sufi Resistance Movements in Western and Russian Scholarship' Die Welt des Islams, vol. 42, no. 2 (2002), 139-73.

${ }^{58}$ Michael A. Reynolds, 'Muslim Mobilization in Imperial Russia's Caucasus' in in Islam and the European Empires, ed. by David Motadel (Oxford: Oxford University Press, 2014), especially 194-95 for details of some of the most destructive and violent measures taken by the Russian command.

${ }^{59}$ On the Company's extension of the Sikhs' recruitment of Yusufzai fighters: John Adye, Sitana: A Mountain Campaign on the Borders of Afghanistan in 1863 (London: Richard Bentley, 1867), 12; Robert Nichols, Settling the Frontier. Land, Law, and Society in the Peshawar Valley, 1500-1900 (Karachi: Oxford University Press, 2001), 277.
} 
more severely, 'expeditions' and 'punitive measures'), which seemed to peak between 1850 and $1853 .^{60}$ The Afridi tribe, for example, kidnapped a European named Mr. Hamilton in $1850 .{ }^{61}$ This was accompanied by tribal 'aggressions', 'raids', and armed 'attacks'. From at least 1851, such activities taking place in the vicinity of the Kohat Pass committed by the Afridis were summarised as 'outrages', the term used through the $1850 \mathrm{~s}$ and $1860 \mathrm{~s}$ to describe the Afridi, Mohmand, Waziri, and other tribes' resistance of colonial political authority. ${ }^{62}$ Within thirteen years of its absorption in 1849, the British had launched twenty punitive expeditions against the frontier tribes in Yaghistan, officially - and retrospectively rationalised as 'measures required for the establishment of a strong rule and a peaceful border in countries which had never before known law and order.' 63

Influencing such opinions was the memory, still fresh in the minds of the expatriate community, of the British retreat from Kabul in 1842, in which some 4,500 troops and around 12,000 civilians died as a result of the attack by tribesmen upon the column passing through the narrow passes or else from the biting January cold in the mountains. From a relative terra incognita before the Anglo-Afghan War, Afghanistan was reconceived as terra nullius, a violent and uncivilised space, as Martin Bayly argues. ${ }^{64}$ In keeping with theories of positivist international law in vogue at the time, diplomatic relations were deemed relatively impossible in such a space, the British Indian state shifting from intervention to non-engagement, from a 'forward policy' of extending imperial influence to the delimitation and closing of the border as the means of defending the empire in south Asia. ${ }^{65}$ Such beliefs were bolstered by experience in the Pashtun and Punjabi Muslim-dominated area of western Punjab. Shortly after the revolt in 1848 of the Sikh-appointed governor of Multan over the payment of dues, two British officers were violently murdered in a surprise mob attack, an 'outrage' from the British point of view that required a sharp and swift response. Around this time, there also loomed concerns that 'various chiefs throughout the province and even the Afghans might seize upon any sign

\footnotetext{
${ }^{60}$ W.H. Paget, Record of the Expeditions Undertaken Against the North-West Frontier Tribes (Calcutta: Superintendent of Government Printing, 1871).

${ }^{61}$ PAL-P, 7.12.1850, Nos. 7-9.

${ }^{62}$ See, for instance: PAL-P, 11.1.1851, Nos. 26-28; PAL-P, 1.2.1851, Nos. 29-30; PAL-P, 9.8.1851, Nos. 16-19 6.9.1851, Nos. 131-133; 4.10.1851, Nos. 61-63; PAL-P, 1.10.1864, Nos. 5-7; 14.3.1868, Nos. 16-18; PAL-P, 28.3.1868, Nos. 43-44.

${ }^{63}$ Imperial Gazetteer of India: North-West Frontier Province (Calcutta: Superintendent Government Printing, 1908), 20, cited in: Kolsky, 'Regime of Exception', 1224.

${ }^{64} \mathrm{Cf}$. Hopkins, 'Frontier Crimes' 370-71 and 375, for a discussion of how the frontier was designated as an anarchic space outside civilisation, and therefore outside the operation of the law applicable to imperial subjects. 65 Bayly, Taming the Imperial Imagination, 179-291. See, also: Lauren Benton, A Search for Sovereignty. Law and Geography in European Empires, 1400-1900 (Cambridge: Cambridge University Press, 2010), 238.
} 
of British weakness or hesitation' to undermine British rule over central Punjab, already annexed in $1846 .{ }^{66}$ The resulting siege of Multan was a signal event in the Second Anglo-Sikh War of 1848-49, the memory of which weighed particularly heavily on the formation of any easy relationship of the expatriate community with Punjabis and Pashtuns. In sum, with the transfer in 1849 of those borderland territories formerly claimed by the Sikhs to the British, therefore, the new colonial administration felt that coercion and violence - rather than law and good government - were the best means with which to assert its sovereignty.

To most effectively exercise their domination, frontier agents thadapted tribesmen's own tactics. Just as tribesmen blockaded the caravan routes or other supply lines to deprive their rivals of subsistence or annoy larger political authority, so, too, did colonial agents institute blockades (bandish) to impoverish tribal families by severing their access to lowland markets and pasturage. ${ }^{67}$ Another strategy was based on baramta, the 'retaliatory seizure of animals, people, and property meant to pressure a community to surrender an alleged criminal or force a monetary settlement'. ${ }^{68}$ Although not as short and sharp as its instigators had hoped, the Ambela campaign of 1863 marked the climax - although not the end - of British punitive action against the Sitana colonists. ${ }^{69}$ British forces succeeded in disintegrating the colony, which struggled to reestablish itself in tribal territory for several decades, while also, to its detriment, losing the nominal support of the influential Akhund of Swat. ${ }^{70}$ British forces continued to fight cruel counterattacks after 1863, clocking a further ten campaigns by the start of the Second Anglo-Afghan War.

Pashtun resistance to the authority (and oppression) of sedentary states was of long-standing, therefore, but was given a new vitality in Pashtun life due to the negative impact of British imperial political economy, not least because of the severance or undermining of those commercial-religious networks which had given the tribes sustenance and identity. ${ }^{71}$ At the same time, Pashtun resistance was understood in entirely new ways within the nineteenth-

\footnotetext{
66 Condos, Insecurity State, 25-66, and the quotation on 36. On the Pashtuns' reluctance to forfeit their independence to the British, and their opportunistic (but unsuccessful) agitation during the 1857 Rebellion: Gaz. Peshawar District, 1897-98 (n.p., 1898), 87.

${ }^{67}$ Olaf Caroe, The Pathans, 550 B.C. - A.D. 1957 (London: Macmillan \& Co, 1958), 350.

${ }^{68}$ Kolsky, 'Regime of Exception', 1224-25

${ }^{69}$ Adye, Sitana, 91-101 for an evaluation of the campaign and a statement of continued anxieties about frontier insecurity. A prior but unsuccessful campaign against the Sitana colonists took place in 1858: PAL-P, 22.5.1858.

${ }^{70}$ Marsden and Hopkins, Fragments, 86.

71 Shah Mahmoud Hanifi, Connecting Histories in Afghanistan. Market Relations and State Formation on a Colonial Frontier (Stanford: Stanford University Press, 2011).
} 
century British colonial state. In the first place, British ideas about Pashtun difference were rooted in the particularities of space and their imagination of the Pashtun within it: the spartan landscape of the highlands - where resources were scarce and competition was acute - which not only necessitated nomadic lifestyles and pastoralism, but also the tribesmen's toughness and strength, his primitiveness and predisposition to violence. British ideas were also racialised, influenced by the relatively recent British historical experience and by a range of evolving ideas about racial difference and descent.

These ideas, secondly, were entangled with a developing sense of religious difference; namely, between belief and praxis on the populous plains earlier colonised and long under the rule of centralised and highly-urbanised states, on the one hand, and that of the sparse upland 'frontier' at further remove from such larger political authority, on the other. In the latter was found the 'the rear-guard of the Mahomedan host,' who differed unfavourably from Muslims in 'the Turkish and Persian nations', commenters questioning the veracity of what was practiced (if at all) by the tribes as Islam, while also fearing a particularly virulent form of belief - the 'fanaticism' associated with Sufism - that had the power to unite the fractious tribes into violent jihad. ${ }^{72}$ Finally, therefore, these connections between conceptions of space, race, and religion were reinforced by a history, marked not only by such episodes as the bloody retreat from Kabul in 1842 or the uprising at Multan of 1848-49, but also by the almost continuous disquiet along the frontier, whether due to raiding and pillaging by dispossessed tribesmen or the activities of the Sitana 'fanatics'. In turn, this history gave rise to the notion of a space that was ungovernable in the absence of strong discipline, and it is to this issue that the remainder of this article turns.

\section{II}

The project of codifying Indian laws into a set of statutes - the Anglo-Indian codes - was begun in the mid-nineteenth century, but these laws were not universal. ${ }^{73}$ Building on the work of legal historians, notably Lauren Benton, scholars have highlighted the legal pluralism and

\footnotetext{
${ }^{72}$ R. H. Davies, Report on the Trade and Resources of the Countries on the North-Western Boundary of British India (Lahore: Government Press, 1862), 3.

${ }^{73}$ The effort to introduce a legal regime of some sort - even if at variance with that prevailing elsewhere in peninsular India - came in consequence of disquiet from certain quarters at 'arbitrary' government in newlyconquered Punjab, where administrators flouted the law and imposed military-authoritarianism; see: Condos, 'Licence to Kill', here especially 494-96.
} 
layered sovereignty at work within colonial India (and, thus, across the British Empire). ${ }^{74}$ The frontier has been a critical site in the scholarly exposition of such complexity, for it was here that the smooth functioning of colonial administration originating from, and refined in, the settled plains and river valleys was perceived to have met its limit - its 'natural frontier' necessitating special laws and administrative arrangements. ${ }^{75}$ At the same time, it is clear that such spaces were thought to produce particular kinds of subjects: untamed and prone to criminality, ungovernable and thus variously in need of extraordinarily harsh discipline or relative latitude and leniency. An examination of two laws - the Frontier Regulations (FR) of 1872 and the Murderous Outrages Act (MOA) of 1867 - and the respective emendations and re-promulgations, elucidates this problematic of colonial rule.

So notorious was the Indo-Afghan frontier, that G.R. Elsmie (1838-1909) - formerly Additional Commissioner and Sessions Judge of Peshawar Division - declared in the preface to his manual for local officers of 1884 that administrators and laymen alike would have heard of the extraordinary crime 'of the worst conceivable kind' that was 'of almost daily occurrence amongst a Pathan people. ${ }^{76}$ Such crimes included kidnapping as well as cattle, camel, and sheep stealing by tribes who were locked into increasingly fierce competition - in the wake of the impoverishments brought by imperial political economy, not that contemporaries much appreciated this fact - over material resources, as well as resentments of long standing, with the Afridis, Orakzais, and Waziris blamed for a considerable amount of the raiding that took place across the frontier. ${ }^{77}$ Yet, the 'principle crime' was 'murder in all its phases', Elsmie puffed, from 'unblushing assassination in broad daylight, before a crowd of witnesses; the carefully-planned secret murder of sleeping victims at dead of night; murder by robbers;

\footnotetext{
74 Lauren Benton, Law and Colonial Cultures. Legal Regimes in World History, 1400-1900 (Cambridge: Cambridge University Press, 2001), especially 127-66. In addition to the citations that follow, see, also: Elizabeth Kolsky, Colonial Justice in British India: White Violence and the Rule of Law (Cambridge: Cambridge University Press, 2009), which observes that, despite the drive to codify Indian laws and thus make more uniform the Indian judicial system, the inclusion of legal entitlements to certain groups immediately opened 'zones of illegality' within the scope of the law.

75 The published Romanes lectures of 1907 delivered at the University of Oxford by George Nathaniel Curzon (1859-1925), formerly Viceroy of India (1899-1905), represents a critically important crystallisation of thinking about the 'natural frontier': Frontiers (Oxford: Clarendon Press, 1907), especially 13-23.

${ }^{76}$ G. R. Elsmie, Notes on Crime and Criminals on the Peshawar Frontier (Lahore: W. Ball, 1884), v, and 1 for citation. For details of Elsmie's service and his role in formulating and developing the Frontier Crimes Regulation: Hopkins, 'Frontier Crimes', 378-79.

77 Report by Robert Montgomery, Esquire, Judicial Commissioner, for the Punjab, and Cis and Trans-Sutlej States, on the Administration of Criminal Justice, and Police Management, for the Year 1853, with an Account of the Local Improvements Effected in the Cis and Trans-Sutlej States, and in the Lahore and Jelum Divisions (Lahore: Chronicle Press, 1854), 125.
} 
murder by rioters; murder by poisoners', to 'murder by boys, and even by women, sword in hand. ${ }^{78}$

Among the common causes for murder were disputes over land, its boundaries, and its resources (including irrigation), as well as murders either committed by thieves and robbers in the course of burglarising or by their victims in defence. Alongside economic competition, however, was the maintenance of honour according to the Pashtun honour code (Pakhtunwali). ${ }^{79}$ Again, contemporary commentators (and historians working with their accounts) may not have been alive to the role of marital alliances in Pashtun society, and thus the especial place of female family members as a political resource, something to which historians of Rajput 'tribes' and 'clans' and royal lineages have been a little more attentive by comparison. ${ }^{80}$ Instead, colonial sources mention only that the 'dishonour' brought upon, or by, female members of a family or tribe was the chief cause of murder, such reference to custom and sentiments only making the Pashtuns seem more archaic and irrational in their being guided only by their passions. It was the problem that British officials felt would be most intractable in light of Pashtun custom. 'No legislative enactments, no punitory measures that could be adopted would stay the hand of a Puthan [sic] from assassinating the author of his shame,' stated the Peshawar District Commissioner, 'so that it is not under this class we may hope to look for a reduction until such time as education and other civilising influences affect the tone of native society. ${ }^{, 81}$ As the number of adulteries increased, so did the murder rate. ${ }^{82}$

If this gave credence to the trope of the Pashtun tribesman as a noble savage, it also supported a patriarchal interpretation of 'his women' as wanton and licentious in ways that provoked (if not, necessitated) his violent acts of vengeance in the maintenance of honour and morality. ${ }^{83}$ Such facts also suggested that Pakhtunwali was upheld even at the expense of the tenets of

\footnotetext{
${ }^{78}$ Elsmie, Notes, citation on 2, and 22-24 for a court summary of a case of murder by an Afghan woman in the Kohat district in August 1873.

${ }^{79}$ Akbar S. Ahmed, Pukhtun Economy and Society. Traditional Structure and Economic Development in a Tribal Society (London: Routledge and Kegan Paul, 1980), chapter 4.

${ }^{80}$ See, above: n. 11.

${ }^{81}$ Report on the Administration of Criminal Justice in the Punjab and its Dependencies During the Year 1868 (Lahore: Punjab Printing Company, 1869), 3-4.

${ }^{82}$ Report on the Administration of Criminal Justice [...] 1868, 77; Report on the Administration of Criminal Justice in the Punjab and its Dependencies During the Year 1871 (Lahore: Punjab Printing Company, 1872 ), 8.

${ }^{83}$ Sexualised understandings of Afghan women perhaps owe something to the British occupation of Kabul in 1839-41, British male officers entered (marital) relationships with (sometimes high-ranking) Afghan women and when a flourishing prostitution racket helped sate the former's carnal desires, in turn prompting outrage at the dishonouring of Afghans; see: William Dalrymple, Return of a King. Shah Shuja and the First Battle for Afghanistan, 1839-42 (London: Bloomsbury 2012), 223-25.
} 
Islam, thus vindicating the belief that the Pashtun were either Muslims in nominal terms or else of so degraded a sort as to not be recognisable to other believers. ${ }^{84}$ In fact, those Europeans facing their fiercest resistance in other Muslim-inhabited uplands were coming to similar conclusions. Russian officers were coming into contact - often savagely - with Muslim tribes in the Caucasus highlands who had long been hostile to imperial authority, facing their fiercest resistance following the establishment of the Sunni-Sufi Imamate of Dagestan in 1828 and the beginning of the holy war against the Russians that reached a pitch under the leadership of Shamil (1797-1871) from 1834 until his capture and surrender in 1859. At the same time, the reports of French colonialists in the north African mountains circulated around the European imperial world, describing resistance by armed Muslim tribes thought to be prone to blood feud and vendetta. British, French, and Russian imperialists and scholarly Orientalists thus sharply distinguished Muslims - often herdsmen and nomads - on the highland frontiers of their empires from those of the settled lowlands and plains. ${ }^{85}$

'[T]here is evidently something in the air of the frontier,' remarked Sir Herbert Edwardes (1819-63), the 'Hero of Multan' of 1848, 'which rouses brutality in every Muhammadan. ${ }^{86}$ Landscape - as a bundle of climate, topography, and ecology - played a vital role in explaining the prevalence of crime, especially violent crime and murder, Peshawar having the highest rate of the latter in Punjab. ${ }^{87}$ Landscape seemed not only to explain the economic precarity that, it was believed, perpetually drove the shepherd to rustling or encroachment on another's land, but also led to the distillation of turbulence and vindictiveness, bravery and independence in the Afghan character, to mark their fundamental racial difference from the yeomen of plains the world over. ${ }^{88}$ Such characteristics, it was also believed, gave shape to Pakhtunwali and explained the Pashtun's flights of violence, including murder. So infectious was the miasma hanging over the frontier, if not of the lure of Pakhtunwali, that it could infect non-Pashtuns: the case of The Crown vs. Lal Singh on the charge of murder, for example, was adjudicated as 'a case of wife murder by a Hindu who seemed to have imbibed Pathan ideas. ${ }^{89}$ Such understandings are explicable in light of the advances in the study of psychiatry, tropical

\footnotetext{
${ }^{84}$ Such confusion has produced considerable anthropological inquiry. See, above: n.5.

85 Jersild, Orientalism and Empire, 3-4, 41-42.

${ }^{86}$ Cited in: Elsmie, Notes, 5.

${ }^{87}$ For discussion of murder rates: Report on the Administration of Criminal Justice in the Punjab and its Dependencies During the Year 1873 (Lahore: Punjab Printing Company, 1874), 13.

${ }^{88}$ For a portrait of the Afghan character and its relationship to the land drawing on a range of prior publications, see: Elsmie, Notes, 4.

${ }^{89}$ Elsmie, Notes, 29-30 for a summary of the case. Hopkins, 'Frontier Crimes', 377, also notes officials' belief that non-Pashtun could become 'Pathanised'.
} 
diseases, and medicine by the latter-half of the nineteenth century that provided a vocabulary to make sense of threats to the colonial order, including 'frontier madness' and flights of violence. $^{90}$

Murder was supposed of an essentially distinctive character on the Indo-Afghan frontier, for the spilling of blood begat vendette that could persist for generations. 'Many years must elapse, and almost a new race arise, before any efficient check can be put to this crime,' John Coke (1806-97), then the Deputy Commissioner of Kohat on the Northwest Frontier, decried a few years after the extension of British administration to the Peshawar valley, for here was to be found 'a race of men who are bred to arms from their childhood, of violent passions, highly sensitive about their women who are always ready to fly to the hills with any good looking young Puthan who takes a fancy to them. ${ }^{91}$ The prevalence of blood feud and vendetta led not only to further crime, but also to the frustration of the colonial justice system, for tribesmen used legal process to press false allegations and present fabricated evidence 'either to divert suspicion from the real criminals or to wreak vengeance upon old enemies. ${ }^{92}$

If the 'exceptional' rate of murder in Peshawar was attributable to 'the frontier position of this district and the character of the people', so, too, was the prosecution of murder at the mercy of the peculiarities of the lay of the land. ${ }^{93}$ The outcome of cases in the 'turbulent district' of Peshawar were 'not very satisfactory', where, of ninety-three murders committed in 1871 , for instance:

five persons only were sentenced to death, five transported for life, and one for a term. In 29 cases the accused were discharged by the Magistrate, and in 20 cases acquitted by the Sessions Court, in 17 the criminals were not known, and in 11 they absconded. ${ }^{94}$

The exceptionally long delays - in the context of Punjab as a whole - between conviction and sentencing due to the difficulty of finding witnesses or gathering (and adjudicating as nonfalsified) evidence in this more remote country, sometimes worked to the advantage of those

\footnotetext{
${ }^{90}$ Kolsky, 'Regime of Exception', 1234-36; Condos, 'Fanaticism', 731-38.

${ }^{91}$ Report by Robert Montgomery, 124.

${ }^{92}$ Elsmie, Notes, 2, and 57-92 for court summaries of such cases.

${ }^{93}$ Report by Robert Montgomery, 123.

${ }^{94}$ Report on the Administration of Criminal Justice [...] 1871, 8.
} 
convicted, whose sentences were thus duly commuted from the full death penalty for murder to transportation. ${ }^{95}$ The ease of absconding to refuge in the remote uplands 'rendered it imperative that too much liberality should not be shewn to offenders', with bail granted if circumstances - such as security deriving from family relations or from hereditary or ancestral lands - made such flight more difficult. ${ }^{96}$ By their own admission, therefore, colonial officers felt there was good cause for a harsh regime. For its part, the state was anxious about such an 'armed and turbulent population' in the wake not only of the events of 1848 and 1857, but also the more frequent challenges to colonial authority described above. ${ }^{97}$ Of the murders - none involving expatriates - reported in 1871 , for which a breakdown is available, " 70 were committed by means of lethal weapons, 28 with fire arms, and 42 with swords, daggers, knives, $\& c$,' the district commissioner concluding that there 'is no doubt that the general possession and use of arms among a population naturally excitable and sensitive, tends to encourage violent crime. ${ }^{98}$

Yet, the very fact of the insecurity of person and property justified the possession of weapons by the populace, so that the Arms Act instituted elsewhere in Punjab after annexation was not extended in its entirety to the frontier. ${ }^{99}$ The Indo-Afghan frontier was awash with weapons, including rifles of local manufacture as well as guns smuggled from abroad. ${ }^{100}$ Of the latter, evidence discovered by the British during the Second Anglo-Afghan War threw into relief the networks connecting 'European firms, Indian merchants, Zanzibari commercial agents, Hindu bankers, and Armenian, Parsi, and Iranian intermediaries' in moving European arms to 'markets along the Gulfs of Persia and Oman.' 101 As to the local production of weapons, the administration was loath to make it illegal for fear of driving the operation underground or across the border, reasoning present demand was sufficiently high as to push up the price and

\footnotetext{
95 See, for example, the case of The Queen vs. Huleem, Khairoola and Jeea for murder in 1866: A.B. Broadway and A.L. Danson, Reprints of the Criminal Rulings of the Chief Court of Punjab. Reported in the Punjab Record, Annotated with Reference to Subsequent Rulings. Vol. I: 1866-1881 (Lahore: Civil and Military Gazette Press, 1911), 135-36.

${ }^{96}$ Report on the Administration of Criminal Justice in the Punjab and its Dependencies During the Year 1867 (Lahore: Punjab Printing Company, 1868), 67.

${ }^{97}$ Report of the Administration of Criminal Justice in the Punjab and its Dependencies, for the Year 1865 (Lahore: Hope Press, 1866), 58.

${ }^{98}$ Report on the Administration of Criminal Justice [...] 1871, 63.

${ }^{99}$ Ibid, 63, including details of complementary protection measures instituted by the state. For a discussion of the disarming of Punjabis after 1849, see: PAL-P, 17.5.1856, Nos. 11-16; Condos, Insecurity State, 105-124.

${ }^{100}$ Report on the Administration of Criminal Justice [...] 1871, 63, for details of production in Kohat.

${ }^{101}$ Robert D. Crews, Afghan Modern. The History of a Global Nation (Cambridge, Mass.: The Belknap Press of Harvard University Press, 2015), 95-96. See, also: Idem, 'Trafficking in Evil? The Global Arms Trade and the Politics of Disorder' in Global Muslims in the Age of Steam and Print, 1850-1930, ed. by James L. Gelvin and Nile Green (Berkeley: University of California Press, 2014)
} 
thereby limit the circulation of arms, this natural equilibrium at risk of being thrown off balance by heavy-handed policy. ${ }^{102}$ Alongside such legislative latitude was a degree of judicial leniency, most notably in the reduction of charges in murder cases to 'culpable homicide'. In the case of Samarcand vs. The Crown in 1866, for instance, the murder charge against a young man trying to avenge his own father's murder (at the hand of another from the rival village faction on the border of Yusufzai territory) was reduced to culpable homicide, the appellant offered either a sentence of ten years' 'rigorous imprisonment' or a fine and two year's incarceration. ${ }^{103}$ In the case of Fuzl Shah vs The Crown in 1866, the charge was reduced to culpable homicide on the grounds that the appellant had been thoroughly provoked by his wife's 'obstinacy' in performance of her duties, the latter having only recently returned following an elopement, the whole case indicative of the frontier administration's patriarchalism born as much of the fascination for Afghan women as the fear and disgust at their sexuality. ${ }^{104}$

In the immediate post-annexation period, the civilising benefits of European power seemed clear to colonial officials, for the man 'who would, five years ago, have looked only to their sword or gun for redress, now may come to [...] Court.' ${ }^{105}$ Another scheme was also underway; that of "collecting the migratory and predatory tribes in the villages, and by supplying land and seed,' would 'win them to agricultural habits', thus ending the pastoral ways of life that had supposedly preserved in them a tendency to barbarism and savagery, much as had been pursued in Scotland. ${ }^{106}$ This was part of a larger and longer-term project of settling the Peshawar frontier, but also the colonial enterprise to 'sedentarise' mobile warrior groups into standing (rather than irregular and seasonal) armies. ${ }^{107}$ These enterprises were partially successful (insofar as people were channelled onto the land or into regiments), but the possibility that the cause of crime might be connected to the wider effects of this new political economy was given no thought, even the more self-confident hopes for the British judicial system were quickly

\footnotetext{
${ }^{102}$ Report on the Administration of Criminal Justice [...] 1871, 63.

${ }^{103}$ Broadway and Danson, Reprints, 90-91, and 379-80 for a similar case (Mahomed Khan and Fuzl Khan vs The Crown) in 1869, and 867-68 for the reduction of the charge to culpable homicide because the offence took place in the course of a robbery.

${ }^{104}$ Broadway and Danson, Reprints, 92-93.

105 Report by Robert Montgomery, 120.

106 Report of the Administration of Criminal Justice in the Punjab and its Dependencies, for the Year 1861 (Lahore: Chronicle Press, 1862), para. 279. For the methods of punishing members of such mobile groups found 'wandering' without permission: Report on the Administration of Criminal Justice [...] 1867, 42.

${ }^{107}$ For discussion of these projects, see: Lally, India and the Silk Roads, chapter 7.
} 
defeated: crime, including murder, remained persistently high, save for the year of the cholera outbreak in $1869 .{ }^{108}$

By the 1880s, however, the Punjab Government reported a decline in the murder rate, which was attributed to 'the introduction and the judicious use of the [Punjab] Frontier Regulations,' of 1872, amended as the Frontier Crimes Regulation (FCR) in 1887 and revised in light of the creation of the NWFP in $1901 .^{109}$ This was a piece of paternalist legislation promulgated by a state that sought to investigate and enshrine the supposedly timeless world of tribal tradition and custom in law. ${ }^{110}$ After the FR came into force, John Gordon Lorimer (1870-1914) - on behalf of the Punjab Government - set out to research the 'customary law' of the Pashtun inhabiting the settled districts, his findings codified into the '1899 Code'. ${ }^{111}$ In all this, the British Indian state was not alone: in the Caucasus, too, Russian administrators and orientalists contrasted Islamic law (sharia) with the customary law of the mountaineers ( 'adat), seeing the former as a newer and more dangerous intrusion, and one that Shamil - the fiercest opponent of colonial rule - had tried to substitute for the latter, which the Russians viewed as prior and more culturally authentic. ${ }^{112}$ From 'adat, much as from Pakhtunwali, sprang the tendency to blood feud but also the characteristic of martial valour that the Europeans at once feared and admired.

Central to the FR, and especially important to the reduction of crime, was the empowerment of Deputy Commissioners to 'refer the question of the guilt or innocence of persons accused of offences to the decision of elders'. ${ }^{113}$ These elders were the adult males who gathered in

\footnotetext{
${ }^{108}$ Report on the Administration of Criminal Justice in the Punjab and its Dependencies During the Year 1869 (Lahore: Lawrence Press, 1870).

${ }^{109}$ Elsmie, Notes, 3, which notes that section IV of the 1872 regulations are the cause of this change. Hopkins' analysis of the FCR relies on the documents edited by Nichols (Frontier Crimes Regulation), the latter volume reproducing only the amended statutes of 1887 and subsequent re-enactments. For the full text of the 1872 regulations and the amendments made to particular laws in 1873, 1874, and 1876, see: Papers Relating to the ReOrganization of the Western and North-Western Frontier of India (London: George Edward Eyre and William Spottiswode, 1878), 119-22. Note that the 1872 law also applied to Baluch tribes, even though this is not the focus here.

${ }^{110}$ The British Indian state's role in the creation of tradition through the empowerment of particular groups, often in consequence of the state's historicist bent and search for historical claims to rights and privileges, has been the subject of much scholarship. For instance: Susan Bayly, Caste, Society and Politics in India from the Eighteenth Century to the Modern Age (Cambridge: Cambridge University Press, 1999); David Washbrook, 'Economic Depression and the Making of 'Traditional Society' in Colonial India 1820-1855' Transactions of the Royal Historical Society, sixth series, vol. 3 (1993), 237-63.

${ }^{111}$ J.G. Lorimer, Customary Law of the Main Tribes in the Peshawar District (Lahore: Civil \& Military Gazette Press, 1899). A revised edition based on further research was published in the next by J.G. Acheson.

${ }^{112}$ Reynolds, 'Muslim Mobilisation', 191, 194, 197; Jersild, Orientalism and Empire, 97-98.

${ }^{113}$ Elsmie, Notes, 3.
} 
villages to hear disputes over land, property, blood feud, injury, or women. These gatherings tribal jirga - were, however, now manifested at the behest of colonial officers, usually of men whose attitudes were favourable to the state, and invested with powers to arbitrate civil and criminal cases where the Deputy Commissioner saw fit. Until the revision of the law, the jirgas were only empowered to institute fines; later, they were permitted to issue seven-year prison sentences, revised in 1901 to include floggings and up to fourteen-year sentences and transportation. Only those cases requiring higher standards of evidence were heard in British courts with the guilty subject to heavier sentences. Of course, the jirga was another partial construction of colonialism, for the diverse tribes' prior acquaintance with - and reliance in the arbitration of disputes upon - the jirga was rather varied, and their rules 'were also highly individuated, with some relying on rawaj (local customary law) to resolve disputes, while others employed precepts of the Pashtunwali' ${ }^{114}$ Yet, as an institution, it was better able to penetrate Afghan society than the British court system - as much making manifest the 'limited Raj' as tacit concession of the frailty of the frontier administration, although at once also 'render[ing] the colonial state the ultimate arbiter of tradition.' ${ }^{115}$

Because adultery was a prime cause of the murder and blood feud plaguing the frontier, the 1872 FR also made provision for the punishment of adulterous women: significantly, such cases were the only to be brought into colonial courts, rather than referred to the jirga. The case of The Empress vs. Halim and Mussammat Wahabjan in 1881, for instance, brought a woman into court on the charge of first-class adultery according to section 8 of the Punjab Frontier Regulation I of 1872, resulting in a sentence of 'three months' rigorous imprisonment'. ${ }^{116}$ Women could also be punished - as in a case of 1875 - for the 'abetment of her own abduction', the charge in this particular case cancelled but nonetheless telling of the danger to the colonial order that Afghan wives and daughters were thought to pose. ${ }^{117}$ The elaboration of the FR enlarged the state's coercive power even as judicial matters were further devolved to the jirga: suspects could be detained for up to three years without a conviction, threats to family or property could be made to force surrender, powers of arrest were granted to anyone (this ability being emphasised among clan leaders friendly to the state), and collective punishment was possible where entire villages or communities were held

\footnotetext{
${ }^{114}$ Hopkins, 'Frontier Crimes', 376.

115 Ibid, 376. Anand A. Yang, The Limited Raj. Agrarian Relations in Colonial India, Saran District, $1793-1920$

(Delhi: Oxford University Press, 1989).

${ }^{116}$ Broadway and Danson, Reprints, 1040-41.

${ }^{117}$ Broadway and Danson, Reprints, 590-91.
} 
accountable for crime. ${ }^{118}$ In this, the law empowered certain members of tribes even as it deprived others of their rights. In the latter scenario, moreover, whole areas could be subjected to a blockade, and members of transgressive communities could be prevented from trade with Peshawar and the towns in the settled areas, at the behest of the jirga. The result was to sever the ties of highlanders from the plains, disrupting an already fragile economy to further impoverish the Pashtun tribes and push them further into theft and other forms of crime. ${ }^{119}$

The discussion has hitherto relied on the (albeit scanty, especially after 1872) court record and reports of judicial administration from the Indo-Afghan frontier. These crimes necessarily took place between Afghans or between other non-Europeans - necessarily, because the passage of the MOA authorised legal proceedings in sessions courts without written record for a particular subset of crimes that most alarmed the colonial state: the 'murder [...] or attempt to murder, any servant of the Queen or other person' that 'the general law of the country [was] not adequate to suppress. ${ }^{120}$ The promulgation of such a draconian law in a province whose inhabitants' loyal service provided the empire with so many of its policemen and so much of its military manpower seems a conundrum. Yet, as Mark Condos argues, the problem with the martial races or noble savages was precisely that they were 'warlike' and 'turbulent'. Whatever their loyalty in 1857 , events such as those in 1848 perpetuated a 'permanent siege mentality'. While some of the threat posed by Pashtuns and Punjabis could be neutered by pacifying or else incorporating them into the colonial military, perpetual insecurity and perceived vulnerability - weakness, in other words, rather than strength - created a felt need for harsh discipline and coercive violence. ${ }^{121}$ Punjab was thus a 'Non-Regulation Province' from its inception, in which the ordinary laws and regulations of British India did not automatically apply, and in which 'the man on the spot' was empowered with wide-ranging discretionary authority. ${ }^{122}$ The various forms of resistance to political authority employed by the Yusufzai and other border tribes, the activities of the Sitana colonists, the development of colonial knowledge about the Pashtun, no matter how faulty - including their susceptibility to

\footnotetext{
118 Nichols, ed., Frontier Crimes Regulation, xv; Hopkins, 'Frontier Crimes', 375.

${ }^{119}$ For the critique of the FCR by the last British Governor of the NWFP: Olaf Caroe, The Pathans, 550 B.C. A.D. 1957 (London: Macmillan \& Co, 1958), especiall 350-59.

${ }^{120}$ For the text of the law, see: William Theobald, The Legislative Acts of the Governor General of India in Council, From 1864 to the End of 1867. Vol. V. 1866, 1867 (Calcutta: Messrs. Thacker, Spink \& Co., 1868), 45963, citations on 460 .

${ }^{121}$ For a condensation of this thesis, see: Condos, 'Licence to Kill', 499-503.

122 Kolsky, 'Regime of Exception', 1219.
} 
charismatic yet militant Sufi leaders and their predilection to violence, and, thus, to ghazism and jihad - served at once to amplify and vindicate the expatriate population's worst fears.

Shortly after assuming his post as Commissioner of Peshawar in 1851, Colonel Frederick Mackeson (1807-53) launched a military expedition into the frontier, one of his targets the colony of 'fanatics' at Sitana, which proceeded into 1853. Sitting on his veranda in September that year, Mackeson was handed a petition and then stabbed in the chest with a large knife, dying several days later, the assassination alleged subsequently to have been at the instigation of the Akhund of Swat. ${ }^{123}$ The murder of Europeans was neither unprecedented before 1849 nor unique to this space, but the incorporation of the Indo-Afghan frontier into the sphere of British control inevitably charged these incidents with political significance, even though it was the intrusion of colonial political authority that caused the very grievances that aggravated the tribesmen to violence. ${ }^{124}$ The archives in Lahore, the capital and administrative centre of Punjab, contains details of a number of these deaths (including those of Boulnois, Hand, Carne and Tapp, and Bean), but a more comprehensive list can be found in a 1910 publication. Its author, Miles Irving notes (not intentionally sardonically) that '[a]fter the annexation of the Punjab it is to the Frontier that we turn for the graves that mark the onward progress of the Pax Britannica. $^{125}$

Of these were not only the graves of those who died fighting in the various punitive expeditions instigated by the colonial government, but also those men murdered by tribesmen or more overtly 'assassinated' as political acts: Michael Healy who was 'destroyed' by the Afridis, 'Messrs. Carne and Tapp, the officers of the Salt Department whose murder in 1851 was the cause of the first Black Mountain expedition', Capt. Grantham, who was murdered the same year, and Lieutenant Arthur Boulnois of the Bengal Engineers, murdered by the Mohmand tribe in $1852 .{ }^{126}$ 'A roll of death sadder than that in battle is the list of those who have perished on the Frontier by assassination', Irving poured, noting the following in the years after

\footnotetext{
${ }^{123}$ H. M. Chichester and James Falkner, 'Mackeson, Frederick (1807-1853), Army Officer in the East India Company' Oxford Dictionary of National Biography (Oxford: Oxford University Press, 2004). Accessed online, 29.7.2019: https://www.oxforddnb.com/view/10.1093/ref:odnb/9780198614128.001.0001/odnb9780198614128-e-17610. For the allegation of the Akhund's involvement: PAL-P, 8.7.1854, Nos. 42-43.

${ }^{124}$ For an attempt to unpick the motives of the 'fanatics' prosecuted under the Murderous Outrages Act from the evidence that remains of the very scant records that were produced: Condos, 'Politics of Resistance', 738-42.

${ }^{125}$ Miles Irving, A List of Inscriptions on Christian Tombs Or Monuments in the Punjab, North-West Frontier Province, Kashmir, and Afghanistan. Vol. II (Lahore: Punjab Government Press, 1910), 7.

${ }^{126}$ Irving, A List, 7, for citation, and 165, for the inscription on Boulnois' grave. For details of Boulnois' death, see: PAL-P, 24.1.1852, Nos. 11-13.
} 
Mackeson's death: Lieutenant Hand, shot near the Khyber Pass in 1857; Major Mecham, shot while travelling from Bannu to Kohat in 1859; Lieutenant Ommanney of the Guides and Major Adams, Deputy Commissioner of Peshawar, in 1865; 'Charles Bean, the manager of a travelling circus, [who] was induced by an Afghan to cross the border and then treacherously shot' in 1867; Major Macdonald, who was killed by Mohmand tribesmen in 1873; and a surgeon, named Smith, and Lieutenant Kinloch, both murdered in 1879. ${ }^{127}$ A particular spike was observed around the time of the Ambela campaign, so that these 'murderous outrages' became associated with the 'fanatic' and the 'Wahhabi', the connection to the latter enduring long after the Wahhabi trials, into the next century. ${ }^{128}$

These assassinations - 'outrages' committed by 'fanatics' - only gave greater cause to latent anxiety. Such panic prompted a response from John Lawrence (1811-79), as Viceroy of India, and formerly Chief Commissioner of Punjab from 1852-59. ${ }^{129}$ The catalyst to action was the failed assassination of the wife of Lieutenant Ashton Brandreth on a February afternoon in 1866 by an Afridi named Summad, who had hoped to murder any European, and whose actions led to his extra-judicial execution by Colonel J.R. Becher, the Commissioner of Peshawar. ${ }^{130}$ Brandreth in fact presented the Bill for the Suppression of Murderous Outrages in Punjab, having earlier forwarded a list - admitted to be incomplete - of sixteen European, Eurasian, and other victims of such outrages since annexation. ${ }^{131}$ The outcome was a piece of legislation: the MOA of 1867, subsequently amended as the so-called 'Ghazi Act' of 1877.

In the ensuing discussion following Brandreth's presentation of the Bill, the legislation on the table was described as a necessary evil - an evil of arbitrary government to counter the evil of such heinous crime and obfuscation of colonial duty as that thought to be crippling Punjab. ${ }^{132}$ There was also repeated mention of the murder of Hindus plying the trade routes from north India to Afghanistan and beyond, however. ${ }^{133}$ This had the effect of expanding what made the

\footnotetext{
${ }^{127}$ Irving, A List, 10.

${ }^{128}$ As expressed by the Commissioner of Peshawar in 1900; see: British Library, IOR/L/P\&S/20/203, 'Statement of Fanatical Outrages in the Northwest Frontier Province and Baluchistan' (1906), 8. The first page of this file tabulates the number of outrages from 1877 to 1905, totalling twenty-three in the Northwest Frontier, of which around half were British officers or soldiers.

${ }^{129}$ The latter post was retitled as Lieutenant-Governor in 1858.

${ }^{130}$ Condos, 'Licence to Kill', 492-93.

${ }^{131}$ Abstract of the Proceedings of the Council of the Governor-General of India, Assembled for the Purpose of Making Law and Regulations. 1867 (Calcutta: Office of Superintendent of Government Printing, 1868), 6. The list is not annexed in this document.

132 Ibid, 8.

${ }^{133}$ Ibid, 7, 9.
} 
'murderous outrages' so shocking: it was not only the brutal and unprovoked nature of the violence, but that it was an assault on the authority of the state, whether personified by its civilian or military representatives, or those merchants whose mobility was predicated on the protection of government. Yet, by and large, this legislation was expressly designed to deal with a particular category of person on the frontier - the 'fanatic' - to whom it thus gave substance, instantiating the bogeyman in the expatriate mind as a category of person in the law. There was considerable discussion over whether the 'fanatic' should be defined or supplementary qualifications be added to describe the category of crime that was being pinpointed by the law, but it was decided that:

The term 'fanatic' was specific enough to denote the kind of persons by whom these crimes had been committed, and meant to apply, and while comprehensive enough to include all fanatics in the limited sense intended by the Select Committee, included none but those who committed these outrages from motives unintelligible except on the supposition of some [...] enthusiasm, monomania, or other such cause. $^{134}$

In effect, this permitted the flexible and creative use of the law as an instrument of coercion where colonial officers saw fit, although it was clear from the discussions that it was crossconfessional murder - that is, the assassination or attack of a Christian (or latterly a Sikh or Hindu) by a Muslim assailant - that was the object of the law, and not the murder of coreligionists. ${ }^{135}$ Overall, the law, like the discourse of the fanatic that was so central to it, was thus a close cousin of the Moplah Act of 1854, which was promulgated to deal with Mappila agrarian violence. ${ }^{136}$

This law had three other significant features, as Kolsky's detailed examination of this remarkable legislation highlights. First, it deprived the 'fanatic' of many of his rights, such as the 'right to legal counsel, the right to have a capital sentence confirmed by a higher tribunal, the right to appeal a conviction, and formal rules of evidence.' ${ }^{137}$ They could be detained for any length of time and were subject to whatever procedures the local official saw fit. Second,

\footnotetext{
${ }^{134}$ Ibid, 90, and 91, 195-99 for further discussion over whether to define the subject of the law more precisely. 135 This precursor, as role model and point of departure, is analysed by: Condos, 'Fanaticism', 720, 728-30. Op. cit., 90-91 for this discussion of the need (or not) to specify the religious background of the assailants and victims. ${ }^{136}$ Condos, 'Fanaticism', especially 730-31; Idem, 'Licence to Kill', 481-82 and n. 11.

${ }^{137}$ Kolsky, 'Regime of Exception', 1221.
} 
it gave extraordinary powers to colonial officials: it gave them formal legal sanction for extrajudicial killings, for they had until now been 'summarily executing suspects and then seeking retrospective immunity', and permitted '[t]rials of fanatics [which] were presided over by sessions judges or commissioners of division (executive officers with no formal legal training) in proceedings in which there were no arguments made and no written records kept. ${ }^{138}$ Upon discussion of the Bill, it was noted that the intention was not to permit extra-judicial killings by 'officers in the trans-Indus territory, but placing the practice under regulation and restraint." ${ }^{139}$ Yet, once in place, the law created a degree of a different sort of insecurity, for there were instances where the administration came to believe they had summarily executed the wrong man. ${ }^{140}$

Finally, the law permitted especially harsh sentences in a bid to discourage further outrages, not only the forfeiture of all the assailant's possessions and property to the government, but also - in the case of the death penalty - a form of (public) execution that abrogated the community's sense of honour or impeded the performance of death rituals (for example, eviscerating corpses where the body was to be buried). ${ }^{141}$ The latter was wildly out of step with punishment in Britain, where gibbeting and public execution were abolished by the time the 1867 act was passed in India. ${ }^{142}$ John Lawrence, then the province's governor, permitted the dead body of Frederick Mackeson's assassin to be burnt and his ashes scattered in the river, for instance, thus preventing an Islamic burial. ${ }^{143}$ In the discussions preceding the passage of the MOA, one of the chief architects of the new Indian laws of the 1860s, Henry Maine (1822-88), rationalised that the punishment should fit the people and place. ${ }^{144} \mathrm{Had}$ an outrage as shocking and awful as those committed in Punjab occurred 'in the most civilised portions of the world let us say in the cities of London or Paris', then 'the murderer would have run much risk of being torn in pieces by the mob.' And 'had [it] been perpetrated in places distantly resembling the Indus frontier, for example, the more westerly States of America, the life of the assassin

\footnotetext{
${ }^{138}$ Ibid, 1221. Theobald, Legislative Acts, 461. Archival traces of these on-the-spot executions are not only scarce, but obviously also rather laconic. See, for instance: PAL-P, 25.9.1858, Nos. 39-41.

${ }^{139}$ Abstract of the Proceedings, 8.

140 See: 'Statement of Fanatical Outrages', 2-7.

141 Theobald, Legislative Acts, 460-61.

142 Note that such executions were earlier ordered against the Mappilas on the same grounds: Condos, 'Fanaticism', 726. For comparison with policies in Russian central Asia, see: Lally, India and the Silk Roads, chapter 7.

${ }^{143}$ Chichester and Falkner, 'Mackeson'. Condos, 'Licence to Kill', 505-09 reviews the incidence, and discussion surrounding, the practice of burning convicted fanatics' bodies.

${ }^{144}$ The scholarship on Henry Maine's career and politics is vast; see: Karuna Mantena, Alibis of Empire. Henry Maine and the Ends of Liberal Imperialism (Princeton: Princeton University Press, 2010)
} 
would not be worth five minutes' purchase. ${ }^{145}$ It is plain to see, as Condos argues, therefore, that the law not only upheld violence but was itself a form of violence used against the colonised, an example of what Jean and John Comaroff have termed 'lawfare'. ${ }^{146}$ And, yet, in this connection of conceptions of landscape to those of race, and of race to the law, the MOA was distinctive in another respect. It was a warlike law for a warlike people inhabiting - and formed - by this very particular space.

\section{Conclusion}

To return to the Indo-Afghan frontier as a site of the 'frontier turn' in imperial history, two larger conclusions follow from the above analysis. The first concerns the importance of landscape. ${ }^{147}$ This is neither to push 'environmental determinism' nor functionalist interpretations of the role of landscape in explaining social organisation, political life, and (the difficulty of) administration and government. ${ }^{148}$ Rather, this article offers a highly contingent, culturalist analysis of landscape, highlighting, for instance, differences of pre-colonial from colonial (and these from indigenous) discourses about Afghans despite their rootedness in a sense of the particularities of the space inhabited by the tribes and the particular lifestyles engendered thereby. Britons on the Indo-Afghan frontier were educated in the Classics and thus inculcated in deeply historicised ways of thinking about pastoralists and uplanders, stemming from the writings of the first-century historian, Tacitus, whose ideas had been revived during the Enlightenment. ${ }^{149}$ These ideas were succoured by recent historical experience in Britain and Ireland; namely, England's defeat of the Jacobite rebels in 1745, the subsequent pacification of the barbarous Highlands, and the taming and incorporation of Scotch uplanders into the Union. Such history fed the Enlightenment project of comparison as a means of ordering and making sense of peoples and places - including the Pashtun of the Indo-Afghan frontier, who became another of the British Empire's 'martial races' of 'noble savages' - with such comparisons becoming gradually more entangled within inquiries over the nineteenth century into the origin of the diverse races and explanation of racial difference, not least the search for the 'lost tribes of Israel' or elaboration of theories of 'Aryan descent'. True, the shepherd's precarity pushed him toward distinctive forms of collectivism and to

\footnotetext{
${ }^{145}$ Abstract of the Proceedings, 196.

${ }^{146}$ Condos, 'Licence to Kill', 488 and passim.

${ }^{147}$ For an alternative set of mobilisations of landscape in frontier studies, see: Bhattacharya and Pachuau, eds., Landscape, Culture, and Belonging.

${ }^{148}$ Ahmed, Pukhtun Economy and Society.

${ }^{149}$ Schama, Landscape and Memory, 81-86.
} 
activities such as brigandage, either for survival or as means of political protest. But colonial administrators understood this within their own cultural-intellectual context, seldom seeing how the imperial political economy had produced or accentuated such circumstances. Such understanding, flawed as it was, nevertheless informed the nature of their response.

And, thus, the second conclusion: that feelings of powerlessness or weakness on the frontier produced a seeming contradiction of government. On the one hand, colonial rule was exerted through coercion and violence: the brutal pacification campaigns following the annexation of the Indo-Afghan frontier, the punitive 'expeditions' against the Sitana colonists and their Pashtun collaborators, the harsh and repressive retaliatory measures against everyday acts of defiance by the tribes to colonial authority and its impositions, trial without record or appeal and summary execution in the most morally abhorrent manner conceivable. The passage of events - really a cat and mouse or cycle of provocation and response - only gave further grist to the conviction that a firm hand was needed against a volatile and warlike people: the carnage following the retreat from Kabul in 1842, the events surrounding the siege of the Multan fort in 1848 , each act of resistance by the tribes, every murder of a European by a Pashtun. The development of ideas about Sufism as an alien presence that had corrupted and incited the Afghans to violence, and the elision of local action with larger concern about the spread of Wahhabism, only underscored the need for containment and the return to the culturally 'authentic'. In all this, the law was critically important: not only the designation of Afghanistan as terra nullius, but also of the northwestern portion of the province of Punjab as a 'frontier', which justified the exertion of British coercive power over diplomacy and normal political relations, and the legitimation of arbitrary justice in the form of the MOA. The latter aimed to empower an administration otherwise quaking in its boots, sanctioning not only the punishment of certain acts of murder as local officers saw fit, but in ways that strived to suppress further expressions of dissent by abrogating the Pashtun moral order.

On the other hand, however, powerlessness also entailed an awareness of the limits of state power and - whether by accident or design - a certain amount of leniency. The frontier administration was too thin, the upland landscape too full of folds and nooks into which purported criminals could escape to evade the colonial justice authorities, and the stock of knowledge about local conditions and custom too faulty - with too much remaining unfamiliar - for the colonial state to attempt to penetrate too deeply into the world of the Pashtun, whether to make firearms illegal or to prosecute crime among the people. But limited power and 
(in)advertent leniency possibly intensified, rather than ameliorated, the violence of colonial governance. By passing civil and criminal cases to jirgas - a circumvention of normal British legal procedure, much as the MOA permitted the suspension of due process - the frontier administration was able to unburden itself of some of the tasks of criminal prosecution, and to disappear from the duty book (and, thus, from the record) a considerable portion of crime and punishment. By at once devolving authority to, and thus empowering, those deemed to be the genuine guardians of communities, the state was also able to obscure its own hand in the production of discord and violence in tribal society of the sort that sustained vendette. In this last, the frontier administration's strategy was not so different from that in peninsular India in spirit so much as the degree of latitude granted to tribal elites as the state's intermediaries with local society. ${ }^{150}$ Indeed, this fact draws two issues to attention: the first concerning the distinctiveness of the frontier from the heartland of colonial rule (if at all or only by degree), and thus the utility of such spatial binaries, the second regarding the generalisability of these conclusions to spaces outside the subcontinent. A satisfactory response is not possible here, save to reiterate the analogies drawn above between the British experience on the Northwest Frontier with the Russian Caucasus, and to reaffirm that the frontier was an imaginative space, for the relationship of landscape to people was drawn in unprecedented and unique ways by the British Indian state from that of their predecessors. ${ }^{151}$

\footnotetext{
${ }^{150}$ See, above: n. 110.

151 The present analysis does not permit the argument, made by Hopkins, that the bundle of epistemology and administration that was crystallised in the FCR was replicated in such locales as the tribal uplands of Kenya: 'Frontier Crimes', 369-70, 383-85.
} 